\title{
Impact of Globalization on Youth Cultural Identity
}

Zarqa Azhar

Department of Sociology, University of Sargodha, Sargodha, Pakistan

Dr. Yasir Nawaz Manj

Department of Sociology, University of Sargodha, Sargodha, Pakistan

\section{Dr.Arshad Hussain Hashmi}

University of Veterinary and Animal Sciences, Lahore,Pakistan

Dr.Farah Riaz

Institute of Rural Home Economics, University of Agriculture, Faisalabad, Pakistan

Tauqeer Ahmed

Department of Sociology, University of Sargodha, Sargodha, Pakistan

Malik Muhammad Sohail

Department of Sociology, University of Sargodha, Sargodha, Pakistan

\section{Doi:10.5901/mjss.2014.v5n23p2198}

\section{Abstract}

There is long debate about globalization and its effects. Globalization is an increased, quantitatively and qualitatively, numbers of global flows improves or deteriorate people's everyday lives. The present study investigates the impact of Globalization on youth cultural practices and preferences in daily life. A descriptive method of research is used to gather information. The universe of this research comprised of the male and female students from different departments of university of Sargodha. The total sample of this study comprises 150 youth male and female students aged 18 to 29 years from 23 departments of university of Sargodha through stratified sampling method. The study employed descriptive statistics to summarize and describe the data whereas inferential statistics such as Chi-square and Gamma test were used to examine the relationship between predictors and response variables. The hypothesis "Gender is associated with the difference in perception about impact of globalization" is accepted. The hypothesis "Higher the adoption of western patterns, more will be the impact of globalization" is accepted.

Keywords: Globalization, Pakistan, Westernization, Youth cultural Identity.

\section{Introduction}

Globalization is a comprehensive phenomenon, and has been defined in several ways. The word globalization is used in different meaning for different people across the globe. Some focus on the economic aspect and emphasize on the global economy view, whereas some focus on the cultural aspects of this phenomenon and how it has effected different aspects of culture, still others focus on the political aspects of the structure of globalization, yet others equate globalization with advanced technology, particularly in the area of communication and transportation. Globalization has achieved the unusual status, in a relatively short time, of becoming fashionable in academic debates in the social sciences, in the business world, and to some extent in the popular media (Walsham, 2001). It is a social process in which the constraints of geography on social and cultural arrangements recede and in which people become increasingly aware that they are receding (Malcolm, 1995). Giddens (1991) suggests that globalization can be defined as "the intensification of worldwide social relations which link distant localities in such a way that local happenings are shaped by events occurring many 
miles away and vice versa". There is a wealth of literature on globalization and identity, what it means and its impact on societies (Held \& McGrew, 2003; Ray, 2007; Robertson, 1992; Tomlinson, 1999; Castells, 1996; Urry, 2003).

According to Tuo (1998) globalization is a process which has an obvious and holistic tendency for integration of human life and this reaches beyond the boundaries of region and nation.

Castells, M (1997) analyzes the importance of identity within the network society of a globalized world. He defines identity as the "process of constructing meaning" by prioritizing a cultural attribute or a set of cultural attributes over other meanings and meanings are organized around a primary identity that is sustained in time and space. Identities, for both social groups and societies, are constructed by processing all the available material history, geography, collective memory, power structures, etc., and are reorganized by actors depending on the social determinations and cultural projects of the social structure within a determined time-space framework that is marked by power relations.

There is straight forward relationship between cultural identity and social concept such as religion, family and gender and it provides the global significance of local knowledge and the sense of self, community and nation. In the identity scenario Deng (2005) points, that cultural identity answers the questions of "Who am I?", "Where are we going?" and "What do we Have?" Since people construct their identities through their cultures, they will defend them and its part of an individual's self-concept (Tajfel, 1984; Livesey, 2004).

Tomlinson (1999) narrates that it is fair to say that the impact of globalization in the cultural sphere has, most generally, been viewed in a pessimistic light. Typically, it has been associated with the destruction of cultural identities, victims of the accelerating destruction of a homogenized, westernized, consumer culture.

According to Giddens (1999) globalization is political, technical and cultural, as well as economic phenomenon. It is 'new' and 'revolutionary' and is mainly due to the immense increase' in financial foreign exchange dealings. This has been facilitated by dramatic improvement in communications technology, especially electronic interchange facilitated by personal computers and other technology. Globalization and Culture are different things to different people. Their relationship to youth and religion is even more ambiguous. Globalization and the emerging culture are deeply intertwined subjects and have a reciprocal relationship (John, 1999).

Globalization creates increased hybridism and differentiation, and overall a more complex and fluid world. Living in a globalized world, he suggests, does not create homogeneity and polarization but rather a creative and eclectic mix of identities. In the context of such a rapidly changing world, young people can find it difficult to construct social identities, particularly with regard to the nature of education, cultural influences and the needs of the labour market (Furlong \& Cartmel, 2007; Waters. M ,1995)).

Interconnection of the whole world, increasing links between the countries is called as globalization. Culture can be defined as our way of life". It is always being associated with the locality, means to say each country have its own cultural identity, which represents it's specify hegemonic globalizations are, in fact, globalized localisms-the new cultural imperialisms(Santos, 2005).

\subsection{Theoretical Framework}

The most comprehensive and accessible sources for addressing issues of theoretical controversy concerning globalization and the contradictory meanings associated with it. Beck divides the theoretical controversy into two major categories, those who point to "one dominant logic of globalization" and that suggesting "a phenomenon with a complex set of causes". The former implies a single cause for globalization, while the latter claims multiple causes for globalization. These theories are divided into the following: capitalist world-system, post international politics, world risk society, the thesis of McDonaldization, globalization and a few other derivations of these interpretations. Wallerstein is one supporter of the capitalist world-system theory. Instead of seeing societies as individual separate entities, Wallerstein sees one world-system in which all things, products and people must accommodate themselves in a single dimension of labor. Capitalism is seen as a "world-system" that "provides the framework for the measurement of social inequalities on a world scale" (Beck, 2000).

Appdurai (1996) describes the dialectical theory on globalization in his "cultural flows" studies. In his book "Modernity at Large". He describes at least four "landscapes" through which people, refugees, tourists, immigrants, exiles and "guest-workers" move on an international level. In his point of view globalization is not seen as the homogenization of culture, but as the ever changing and "flowing" of technology "techno-scapes", economy "finance-scapes", media "mediascapes" and ideology "ideo-scapes" through the movement of people over cultural and national boundaries. These "flows" through "-scapes" change the conceptions of "center" and "periphery" and create imagined worlds that are created by different people and groups.

The theory of the world risk society differs from the above mentioned theories in that it concentrates on more 
ethical questions; ecological catastrophes, humanitarian crises, economical imbalance, technological-industrial dangers and genetic-engineering threats. "Threats create society, and global threats create global society". World risk society implies that trans-national social spaces are born through "unintended, denied or repressed threats" and conflicts. The threat of cultural uniformity is referred to as "McDonaldization". The globalization of world economy and the development of trans-national markets have caused a worldwide generation of hamburger eating, coca-cola drinking, cell phone kids. The threat to local cultures and the extinction of cultural and ethnic diversity seems inevitable (Beck, 2000).

Robertson (1992) suggests that the global process must have roots, a place, origin, locality; even trans-national firms must develop local connections for their businesses. It is called localization of the global, or de-location or relocation of globalization. Globalization is developing its own local cultural traits and dimensions. This process is called "glocalization." So to understand globalization one must understand the world and how culture, diversity, politics, ethnicity, race and homogeneity are manifested. For the generations of people who are accustomed to understanding and defining the world through narrowly and artificially constructed national identities it is a challenge to break from these conceptions of identity. Cultural globalization theorists sense a change in the public, which they claim is partially due to the media's attention on global events and the emphasis on the inter-dependency of humanity.

\subsection{Objective of the study}

- To find out the background characteristic of the respondent.

- To study the impacts of globalization on cultural identity crisis among youth.

- To investigate the hegemony of Western culture on local culture

- To see the impact of Globalization on youth cultural practices.

- To see the impact of western culture on youth appearance and life style

- To examine the impact of western imperialism on our national state sovereignty.

\subsection{Conceptual Frame Work}

\begin{tabular}{|l|l|l|}
\hline Background variables & Independent Variables & Dependent Variable \\
\hline Age & Globalization & \\
Gender & Technological changes & Socio-Cultural identity of Youth \\
Education & Cultural -Imperialism & \\
Income & Westernization & \\
Locality & & \\
\hline
\end{tabular}

\section{Research Methodology}

A descriptive method of research is used to gather information and describe characteristics of variables of interest in a situation. The goal of descriptive study, therefore, is to offer to the researcher a profile or to describe relevant aspects of the phenomenon of interest from an individual, organizational or other perspective (Sekaran, 2010). The universe of this research comprised of the male and female students from different departments of university of Sargodha. Due to the time and budget limitations, the total area covered by the study was university of Sargodha only. Researcher is almost never able to study the all members of the population that interest him so the sample from population was selected. Even a modest sized survey typically requires considerable time, material, money and assistance. According to Wimmer and Dominick (1993) "a sample is the subset of the population that is taken to be the representative of the entire population". In the light of the above definition, researcher selected the youth population from university of Sargodha as a field of study because he wants to see the impact of globalization on socio- cultural identity among youth. So university is the best field of study to represent the youth population. The total population of this study comprises 150 youth male and female students aged 18 to 29 years from 23 departments of university of Sargodha through stratified sampling method.. Before starting data collection, each of the respondents will be taken into confidence for their provided information to be kept confidential. The study employed descriptive statistics to summarize and describe the data whereas inferential statistics such as Chi-square and Gamma test were used to examine the relationship between predictors and response variables. 


\section{Main Findings}

\begin{tabular}{|l|c|c|}
\hline Gender & Frequency & Percentage \\
\hline Male & 75 & 50.0 \\
\hline Female & 75 & 50.0 \\
\hline Total & 150 & 100.0 \\
\hline Age (in years) & 31 & 20.7 \\
\hline 18 to 21 years & 99 & 66.0 \\
\hline 22 to 25 years & 20 & 13.3 \\
\hline 26 to 29 years & \multicolumn{2}{|c|}{} \\
\hline Locality & 33 & 22.0 \\
\hline Rural & 41 & 27.3 \\
\hline Urban/semi-town & 76 & 50.7 \\
\hline Urban/city & \multicolumn{2}{|l|}{} \\
\hline Income (Rs.) & 61 & 40.7 \\
\hline Up to 20,000 & 37 & 24.7 \\
\hline 21,000 to 30,000 & 15 & 10.0 \\
\hline 31,000 to 40,000 & 37 & 24.7 \\
\hline Above 40,000 & 27 & 18.0 \\
\hline Education level & 112 & 74.7 \\
\hline Graduation & 11 & 7.3 \\
\hline Master & \multicolumn{2}{|l}{} \\
\hline M. Phil & \multicolumn{2}{|l}{} \\
\hline
\end{tabular}

Table shows that about a half $(50.0 \%)$ of the respondents were males and other half of them were females. Table also presents the age distribution of the respondents. About one-fifth i.e. 20.7 percent of the respondents were having age 1821 years, while a majority i.e. 66.0 percent of them were having age 22-24 years and remaining 13.3 percent of them had 25-28 years of age. Above table 3 reveals that 22.0 percent of the respondents belonged to rural/village areas, while more than one-fourth i.e. 27.3 percent of them belonged to urban/semi town area and about a half i.e. 50.7 percent of them belonged to city/urban areas. So majority of the sampled youth belonged to urban areas. Above table 4 indicates that 18.0 percent of the respondents were having BA/B.Sc. (Hons.) level of education, while large majorities i.e. 74.7 percent of the respondents were M.A/M.Sc. and remaining 7.3 percent of the respondents were having M. Phil level of education. Table shows that only 8.0 percent of the respondents had Rs. 15000-20000 monthly family income, while 12.7 percent of them had Rs. 21000-25000 monthly family income and 17.3 percent of them had Rs. 26000-30000 monthly income. About one-third i.e. 32.7 percent of the respondents had Rs. 31000-35000 monthly family income and 29.3 percent of them had above Rs. 35000 monthly family income. So majority of the respondents had good economic status.

3.1 Percentage distribution of the respondents according to their opinion about the impact of globalization on interaction pattern

$\mathrm{N}=150$

\begin{tabular}{|c|c|c|c|c|c|c|c|c|}
\hline \multirow{2}{*}{ Impact on interaction pattern } & \multicolumn{2}{|c|}{ Strongly agree } & \multicolumn{2}{|c|}{\begin{tabular}{|l|l|} 
Agree & Neutral \\
\end{tabular}} & \multicolumn{2}{|c|}{ Disagree } & \multicolumn{2}{|c|}{ Strongly disagree } \\
\hline & $\mathrm{F}$. & $\%$ & F. $\%$ & F. $\%$ & F. & $\%$ & F. & $\%$ \\
\hline 1 have access to internet on my cell phone & 71 & 47.3 & 16 10.7 & \begin{tabular}{l|l}
3 & 2.0 \\
\end{tabular} & 36 & 24.0 & 24 & 16.0 \\
\hline I feel that cell phone made my life better & 39 & 26.0 & $24|16.0| 2$ & $22 \mid 14.7$ & 33 & 22.0 & 12 & 8.0 \\
\hline I use to cell phone for chatting with my friends & 68 & 45.3 & $65 \mid 43.3$ & \begin{tabular}{l|l|l}
13 & 8.7 \\
\end{tabular} & 3 & 2.0 & 1 & 0.7 \\
\hline I feel that using cell phone decreased our family bonding & 48 & 32.0 & 5738.0 & $15 \mid 10.0$ & 24 & 16.0 & 6 & 4.0 \\
\hline I have my personal laptop or Computer & 94 & 62.7 & 3825.3 & \begin{tabular}{l|l|l}
3 & 2.0 \\
\end{tabular} & 12 & 8.0 & 3 & 2.0 \\
\hline I have access to television cable channels & 81 & 54.0 & \begin{tabular}{|l|l|}
4429.3 \\
\end{tabular} & \begin{tabular}{l|l|l}
7 & 4.7
\end{tabular} & 16 & 10.7 & 2 & 1.3 \\
\hline \begin{tabular}{|l} 
II likely to watch cable TV alone \\
\end{tabular} & 32 & 21.3 & 3020.0 & \begin{tabular}{l|l}
30 & 20.0 \\
\end{tabular} & 39 & 26.0 & 19 & 12.7 \\
\hline I have access to the internet (world wide web) & 84 & 56.0 & 4832.0 & \begin{tabular}{l|l|l}
3 & 2.0 \\
\end{tabular} & 11 & 7.3 & 4 & 2.7 \\
\hline I mostly prefer to use internet channels (face book, Skype, yahoo etc) to interact with my friends. & 71 & 47.3 & 5033.3 & \begin{tabular}{l|l|l}
10 & 6.7
\end{tabular} & 10 & 6.7 & 9 & 6.0 \\
\hline I spend more than two hour on internet and watching TV & 46 & 30.7 & $57 \mid 38.0$ & \begin{tabular}{l|l}
11 & 7.3
\end{tabular} & 30 & 20.0 & 6 & 4.0 \\
\hline I prefer to call my family and friends instead of face to face interaction & 25 & 16.7 & 5335.3 & $18 \mid 12.0$ & 35 & 23.3 & 19 & 12.7 \\
\hline I feel that social media took us far from real life & 55 & 36.7 & 5939.3 & \begin{tabular}{l|l|l}
22 & 14.7 \\
\end{tabular} & 10 & 6.7 & 4 & 2.7 \\
\hline I feel that face to face Interaction with family decreased due to social media & 43 & 28.7 & 8154.0 & 117.3 & 12 & 8.0 & 3 & 2.0 \\
\hline I feel that face to face interaction decreased with my friends due to cell phone and social media & 42 & 28.0 & 6744.7 & \begin{tabular}{l|l|l}
13 & 8.7 \\
\end{tabular} & 23 & 15.3 & 5 & 3.3 \\
\hline I don't like to be disturbed by my family while watching TV or using internet & 32 & 21.3 & 3120.72 & $23 \mid 15.3$ & 46 & 30.7 & 18 & 12.0 \\
\hline I feel that social media decreased my time spending with my family and friends & 49 & 32.7 & \begin{tabular}{|l|l|l|}
58 & 38.7 \\
\end{tabular} & \begin{tabular}{l|l|l}
11 & 7.3 \\
\end{tabular} & 21 & 14.0 & 11 & 7.3 \\
\hline
\end{tabular}


Table 1 presents the respondents' opinion about the impact of globalization on interaction patters. A major proportion i.e. 47.3 percent of the respondents was strongly agreed and 10.7 percent of them were agreed with the statement "I have access to internet on my cell phone", while 2.0 percent of them were neutral, 24.0 percent of them were disagreed and 16.0 percent of them were strongly disagreed with this statement. So, more than a half of the youth had opinion that they have access to internet on their cell phone.

Little more than one-fourth i.e. 26.0 percent of the respondents were strongly agreed and 16.7 percent of them were agreed with the statement "I feel that cell phone made my life better", while 14.7 percent of them were neutral, 22.0 percent of them were disagreed and 8.0 percent of them were strongly disagreed with this statement.

A major proportion i.e. 45.3 percent of the respondents were strongly agreed and 43.3 percent of them were agreed with the statement "I use to cell phone for chatting with my friends", while 8.7 percent of them were neutral, 2.0 percent of them were disagreed and only one respondent was strongly disagreed with this statement. It's clear from this statement a huge majority of the respondents used cell phone for chatting and communication with their friends.

Slightly less than one-third i.e. 32.0 percent of the respondents were strongly agreed and 38.0 percent of them were agreed with the statement "I feel that using cell phone decreased our family bonding", while 10.0 percent of them were neutral, 16.0 percent of them were disagreed and only 4.0 percent of the respondents were strongly disagreed with this statement. So majority of the youth felt that use of cell phone decreased their family bonding.

A majority i.e. 62.7 percent of the respondents were strongly agreed and about one-fourth i.e. 25.3 percent of them were agreed with the statement "I have my personal laptop or computer", while 2.0 percent of them were neutral, 8.0 percent of them were disagreed and only 2.0 percent of the respondents were strongly disagreed with this statement. So a vast majority of the youth had personal laptop or computer.

More than a half i.e. 54.0 percent of the respondents were strongly agreed and 29.3 percent of them were agreed with the statement "I have access to television cable channels", while 4.7 percent of them were neutral, 10.7 percent of them were disagreed and only 1.3 percent of the respondents were strongly disagreed with this statement. These findings indicating that majority of the selected youth were having access to television cable channels.

More than one-fifth i.e. 21.3 percent of the respondents were strongly agreed and 20.0 percent of them were agreed with the statement "I likely to watch cable TV alone", while another 20.0 percent of them were neutral, 26.0 percent of them were disagreed and 12.7 percent of the respondents were strongly disagreed with this statement.

A majority i.e. 56.0 percent of the respondents was strongly agreed and 32.0 percent of them were agreed with the statement "I have access to the internet (World Wide Web)", while only 2.0 percent of them were neutral, 7.3 percent of them were disagreed and only 2.7 percent of the respondents were strongly disagreed with this statement. So a huge majority of youth were having access to the internet.

A major proportion i.e. 47.3 percent of the respondents were strongly agreed and 33.3 percent of them were agreed with the statement "I mostly prefer to use internet channels (face book, Skype, yahoo etc) to interact with my friends", while only 6.7 percent of them were neutral, another 6.7 percent of them were disagreed and 6.0 percent of the respondents were strongly disagreed with this statement.

Almost 31 percent of the respondents were strongly agreed and 38.0 percent of them were agreed with the statement "I spend more than two hours on internet and watching TV", while 7.3 percent of them were neutral, 20.0 percent of them were disagreed and only 4.0 percent of the respondents were strongly disagreed with this statement.

About 16.7 percent of the respondents were strongly agreed and more than one-third i.e. 35.3 percent of them were agreed with the statement "I prefer to call my family and friends instead of face to face interaction", while 12.0 percent of them were neutral, 23.3 percent of them were disagreed and 12.7 percent of the respondents were strongly disagreed with this statement.

More than one-third i.e. 36.7 percent of the respondents were strongly agreed and 39.3 percent of them were agreed with the statement "I feel that social media took us far from real life", while 14.7 percent of them were neutral, 6.7 percent of them were disagreed and 2.7 percent of the respondents were strongly disagreed with this statement. So these findings show that the social media took us far from real life.

About 28.7 percent of the respondents were strongly agreed and a majority i.e. 54.0 percent of them were agreed with the statement "I feel that face to face Interaction with family decreased due to social media", while 7.3 percent of them were neutral, 8.0 percent of them were disagreed and 2.0 percent of the respondents were strongly disagreed with this statement. So majority of the youth were agreed that face to face interaction with family decreased due to social media.

About 28.0 percent of the respondents were strongly agreed and a major proportion i.e. 44.7 percent of them were agreed with the statement "I feel that face to face interaction decreased with my friends due to cell phone and social media", while 8.7 percent of them were neutral, 15.3 percent of them were disagreed and 3.3 percent of the respondents 
were strongly disagreed with this statement. These results reflects that the our youth felt that face to face interaction decreased with friends due to cell phone and social media.

Little more than one-fifth i.e. 21.3 percent of the respondents were strongly agreed and 20.7 percent of them were agreed with the statement "I don't like to be disturbed by my family while watching TV or using internet", while 15.3 percent of them were neutral, 30.7 percent of them were disagreed and 12.0 percent of the respondents were strongly disagreed with this statement.

Slightly less than one-third i.e. 32.7 percent of the respondents were strongly agreed and 38.7 percent of them were agreed with the statement "I feel that social media decreased my time spending with my family and friends", while 7.3 percent of them were neutral, 14.0 percent of them were disagreed and 7.3 percent of the respondents were strongly disagreed with this statement.

\subsection{Distribution of the respondents according to their opinion about the cultural practices (food pattern)}

$N=150$

\begin{tabular}{|c|c|c|c|c|c|c|c|c|c|c|}
\hline \multirow[t]{2}{*}{ Statements } & \multicolumn{2}{|c|}{$\begin{array}{l}\text { Strongly } \\
\text { agree }\end{array}$} & \multicolumn{2}{|c|}{ Agree } & \multicolumn{2}{|c|}{ Neutral } & \multicolumn{2}{|c|}{ Disagree } & \multicolumn{2}{|c|}{$\begin{array}{l}\text { Strongly } \\
\text { disagree }\end{array}$} \\
\hline & $\mathrm{F}$. & $\%$ & F. & $\%$ & F. & $\%$ & $\mathrm{~F}$. & $\%$ & $\mathrm{~F}$. & $\%$ \\
\hline I mostly like to see foreign TV channels & 39 & 26.0 & 50 & 33.3 & 20 & 13.3 & 33 & 22.0 & 8 & 5.3 \\
\hline TV Channels are the best source of learning new fast food products & 57 & 38.0 & 60 & 40.0 & 23 & 15.3 & 8 & 5.3 & 2 & 1.3 \\
\hline I learn new food pattern from TV channels and mass media & 42 & 28.0 & 65 & 43.3 & 23 & 15.3 & 18 & 12.0 & 2 & 1.3 \\
\hline I like fast food instead of local products & 38 & 25.3 & 50 & 33.3 & 25 & 16.7 & 33 & 22.0 & 4 & 2.7 \\
\hline Mostly youth prefer to go on MNC,s food restaurant & 49 & 32.7 & 69 & 46.0 & 12 & 8.0 & 16 & 10.7 & 4 & 2.7 \\
\hline I feel that fast foods products are more tasty & 39 & 26.0 & 75 & 50.0 & 21 & 14.0 & 12 & 8.0 & 3 & 2.0 \\
\hline I think that TV advertisement change the buying behavior of youth & 61 & 40.7 & 73 & 48.7 & 7 & 4.7 & 4 & 2.7 & 5 & 3.3 \\
\hline $\begin{array}{l}\text { I feel that foreign fast food products decreased the importance of } \\
\text { our local products }\end{array}$ & 61 & 40.7 & 61 & 40.7 & 14 & 9.3 & 12 & 8.0 & 2 & 1.3 \\
\hline $\begin{array}{l}\text { I feel that Mnc's fast food products decreased the importance of our } \\
\text { local food products }\end{array}$ & 50 & 33.3 & 71 & 47.3 & 11 & 7.3 & 13 & 8.7 & 5 & 3.3 \\
\hline
\end{tabular}

Table 2 represents the respondents' opinion about the cultural practices towards food pattern. About one-fourth i.e. 26.0 percent of the respondents were strongly agreed, while about one-third i.e. 33.3 percent of them were agreed with the opinion "I mostly like to see foreign TV channels", while 13.3 percent of them were neutral, 22.0 percent of them were disagreed and only 5.3 percent of them were strongly disagreed with this opinion. So more than a half of the respondents had opinion that mostly youth like to see foreign TV channels.

More than one-third i.e. 38.0 percent of the respondents were strongly agreed, while most of them i.e. 40.0 percent were agreed with the opinion "TV Channels are the best source of learning new fast food products", while 15.3 percent of them were neutral, 5.3 percent of them were disagreed and only 1.3 percent of them were strongly disagreed with this opinion. These findings depicts that majority of the respondents felt that the TV channels are the best source of learning new fast food products.

About 28.0 percent of the respondents were strongly agreed and a major proportion i.e. 43.3 percent of them were agreed with the opinion "I learn new food pattern from TV channels and mass media", while 15.3 percent of them were neutral, 12.0 percent of them were disagreed and only 1.3 percent of them were strongly disagreed with this opinion. These findings show that we learn new food pattern from TV channels and mass media.

About one-fourth i.e. 25.3 percent of the respondents were strongly agreed and about one-third i.e. 33.3 percent of them were agreed with the opinion "I like fast food instead of local products", while 16.7 percent of them were neutral, 22.0 percent of them were disagreed and only 2.7 percent of them were strongly disagreed with this opinion.

About one-third i.e. 32.7 percent of the respondents were strongly agreed and a major proportion i.e. 46.0 percent of them were agreed with the opinion "Mostly youth prefer to go on MNC,s food restaurant", while 8.0 percent of them were neutral, 10.7 percent of them were disagreed and only 2.7 percent of them were strongly disagreed with this opinion. So mostly youth prefer to go on MNC's food restaurant.

Little more than one-fourth i.e. 26.0 percent of the respondents were strongly agreed and about a half i.e. 50.0 percent of them were agreed with the opinion "I feel that fast foods products are more tasty", while 14.0 percent of them were neutral, 8.0 percent of them were disagreed and only 2.0 percent of them were strongly disagreed with this opinion. These findings show that our youth felt that the fast foods products are more tasty.

About 40.7 percent of the respondents were strongly agreed and little less than a half i.e. 48.7 percent of them 
were agreed with the opinion "I think that TV advertisement change the buying behavior of youth", while 4.7 percent of them were neutral, 2.7 percent of them were disagreed and only 3.3 percent of them were strongly disagreed with this opinion.

Almost 41 percent of the respondents were strongly agreed and 40.7 percent of them were agreed with the opinion "I feel that foreign fast food products decreased the importance of our local products", while 9.3 percent of them were neutral, 8.0 percent of them were disagreed and only 1.3 percent of them were strongly disagreed with this opinion. These results depicts our youth felt that foreign fast food products decreased the importance of our local products.

About one-third i.e. 33.3 percent of the respondents were strongly agreed and 47.3 percent of them were agreed with the opinion "I feel that Mnc's fast food products decreased the importance of our local food products", while 7.3 percent of them were neutral, 8.7 percent of them were disagreed and only 3.3 percent of them were strongly disagreed with this opinion.

\subsection{Distribution of the respondents according to their cultural practices (dress pattern)}

$N=150$

\begin{tabular}{|c|c|c|c|c|c|c|c|c|c|c|}
\hline \multirow[t]{2}{*}{ Statements } & \multicolumn{2}{|c|}{$\begin{array}{l}\text { Strongly } \\
\text { agree }\end{array}$} & \multicolumn{2}{|c|}{ Agree } & \multicolumn{2}{|c|}{ Neutral } & \multicolumn{2}{|c|}{ Disagree } & \multicolumn{2}{|c|}{$\begin{array}{l}\text { Strongly } \\
\text { disagree }\end{array}$} \\
\hline & $\mathrm{F}$. & $\%$ & $\mathrm{~F}$. & $\%$ & $\mathrm{~F}$. & $\%$ & F. & $\%$ & $\mathrm{~F}$. & $\%$ \\
\hline $\begin{array}{l}\text { I think cable channels are best source of learning about new dress } \\
\text { pattern }\end{array}$ & 60 & 40.0 & 64 & 42.7 & 14 & 9.3 & 8 & 5.3 & 4 & 2.7 \\
\hline I like to wear western dress & 19 & 12.7 & 56 & 37.3 & 34 & 22.7 & 25 & 16.7 & 16 & 10.7 \\
\hline I feel that foreign dressing decreased the value of our local dress & 51 & 34.0 & 68 & 45.3 & 14 & 9.3 & 13 & 8.7 & 4 & 2.7 \\
\hline I likely to discuss about new dress pattern with my friends & 30 & 20.0 & 49 & 32.7 & 21 & 14.0 & 31 & 20.7 & 19 & 12.7 \\
\hline wearing foreign dress has become the part of my life & 21 & 14.0 & 40 & 26.7 & 21 & 14.0 & 39 & 26.0 & 29 & 19.3 \\
\hline
\end{tabular}

Table 3 represents the respondents' opinion about the cultural practices towards dress pattern. About 40.0 percent of the respondents were strongly agreed and a major proportion i.e. 42.7 percent of them were agreed with the opinion "I think cable channels are best source of learning about new dress pattern", while 9.3 percent of them were neutral, 5.3 percent of them were disagreed and only 2.7 percent of them were strongly disagreed with this opinion. These findings depicts that a huge majority of youth had thinking that the cable channels are best source of learning about new dress pattern.

Only 12.7 percent of the respondents were strongly agreed and more than one-third i.e. 37.3 percent of them were agreed with the opinion "I like to wear western dress", while 22.7 percent of them were neutral, 16.7 percent of them were disagreed and 10.7 percent of them were strongly disagreed with this opinion.

About one-third i.e. 34.0 percent of the respondents were strongly agreed and a major proportion i.e. 45.3 percent of them were agreed with the opinion "I feel that foreign dressing decreased the value of our local dress", while 9.3 percent of them were neutral, 8.7 percent of them were disagreed and just 2.7 percent of them were strongly disagreed with this opinion. So a large majority of the respondents felt that foreign dressing decreased the value of our local dress.

About one-fifth i.e. 20.0 percent of the respondents were strongly agreed and little less than one-third i.e. 32.7 percent of them were agreed with the opinion "I likely to discuss about new dress pattern with my friends", while 14.0 percent of them were neutral, 20.7 percent of them were disagreed and 12.7 percent of them were strongly disagreed with this opinion. These results shows that about a half of them were liked to discuss about new dress pattern with their friends.

About 14.0 percent of the respondents were strongly agreed and more than one-fourth i.e. 26.7 percent of them were agreed with the opinion "wearing foreign dress had become the part of my life", while 14.0 percent of them were neutral, more than one-fourth i.e. 26.0 percent of them were disagreed and 19.3 percent of them were strongly disagreed with this opinion. So majority of the youth had opinion that that wearing foreign dress had not become the part of our society. 


\subsection{Distribution of the respondents according to their cultural practices (languages)}

\begin{tabular}{|c|c|c|c|c|c|c|c|c|c|c|}
\hline \multirow[t]{2}{*}{ Statements } & \multicolumn{2}{|c|}{$\begin{array}{l}\text { Strongly } \\
\text { agree }\end{array}$} & \multicolumn{2}{|c|}{ Agree } & \multicolumn{2}{|c|}{ Neutral } & \multicolumn{2}{|c|}{ Disagree } & \multicolumn{2}{|c|}{$\begin{array}{l}\text { Strongly } \\
\text { disagree }\end{array}$} \\
\hline & $\mathrm{F}$. & $\%$ & $\mathrm{~F}$. & $\%$ & F. & $\%$ & $\mathrm{~F}$. & $\%$ & $\mathrm{~F}$. & $\%$ \\
\hline $\begin{array}{l}\text { I think cable TV, mass media and internet are the source of learning } \\
\text { foreign languages }\end{array}$ & 63 & 42.0 & 64 & 42.7 & 14 & 9.3 & 5 & 3.3 & 4 & 2.7 \\
\hline English language has become an international language now a days & 72 & 48.0 & 63 & 42.0 & 8 & 5.3 & 6 & 4.0 & 1 & 0.7 \\
\hline I prefer to use English language to speak with my friends & 22 & 14.7 & 23 & 15.3 & 32 & 21.3 & 59 & 39.3 & 14 & 9.3 \\
\hline $\begin{array}{l}\text { I mostly use to prefer English words when I chat with my friends on } \\
\text { face book or cell phone }\end{array}$ & 38 & 25.3 & 64 & 42.7 & 25 & 16.7 & 16 & 10.7 & 7 & 4.7 \\
\hline $\begin{array}{l}\text { English medium has become important part of courses in Higher } \\
\text { Education system }\end{array}$ & 81 & 54.0 & 48 & 32.0 & 17 & 11.3 & 4 & 2.7 & 0 & 0.0 \\
\hline Mostly academic courses are taught in English language & 72 & 48.0 & 68 & 45.3 & 6 & 4.0 & 3 & 2.0 & 1 & 0.7 \\
\hline $\begin{array}{l}\text { I feel that English language decreased the superiority of my national } \\
\text { language }\end{array}$ & 71 & 47.3 & 64 & 42.7 & 8 & 5.3 & 4 & 2.7 & 3 & 2.0 \\
\hline $\begin{array}{l}\text { The importance of our national and mother languages decreased by } \\
\text { the dominancy of English language }\end{array}$ & 67 & 44.7 & 64 & 42.7 & 13 & 8.7 & 5 & 3.3 & 1 & 0.7 \\
\hline
\end{tabular}

This Table 4 represents the respondents' opinion about the cultural practices towards dress language. About 42.0 percent of the respondents were strongly agreed and a major proportion i.e. 42.7 percent of them were agreed with the statement "I think cable TV, mass media and internet are the source of learning foreign languages", while 9.3 percent of them were neutral, 3.3 percent of them were disagreed and only 2.7 percent of them were strongly disagreed with this opinion. So a huge majority of the respondents had thinking that the cable TV, mass media and internet are the source of learning foreign languages.

Little less than a half i.e. 48.0 percent of the respondents were strongly agreed and 42.0 percent of them were agreed with the statement "English language has become an international language now a days", while only 5.3 percent of them were neutral, 4.0 percent of them were disagreed and only one respondents was strongly disagreed with this statement. These results depicts that our youth felt that the English language has become an international language now a days.

Only 14.7 percent of the respondents were strongly agreed and 15.3 percent of them were agreed with the statement "I prefer to use English language to speak with my friends", while 21.3 percent of them were neutral, 39.3 percent of them were disagreed and 9.3 percent of the respondents was strongly disagreed with this statement. These findings show that our youth do not prefer to use of English language to speak with their friends.

About one-fourth i.e. 25.3 percent of the respondents were strongly agreed and a major proportion i.e. 42.7 percent of them were agreed with the statement "I mostly use to prefer English words when I chat with my friends on face book or cell phone", while 16.7 percent of them were neutral, 10.7 percent of them were disagreed and 4.7 percent of the respondents was strongly disagreed with this statement. So our youth mostly use to prefer English words when they chat with their friends on face book or cell phone.

A majority i.e. 54.0 percent of the respondents were strongly agreed and about one-third i.e. 32.0 percent of them were agreed with the statement "English medium has become important part of courses in Higher Education system", while 11.3 percent of them were neutral, 2.7 percent of them were disagreed with this statement. It's clear from these results that the English medium has become important part of courses in Higher Education system.

A major proportion i.e. 48.0 percent of the respondents were strongly agreed and 45.0 percent of them were agreed with the statement "mostly academic courses are taught in English language", while only 4.0 percent of them were neutral, 2.0 percent of them were disagreed and only one respondent was strongly disagreed with this statement. So mostly academic courses are taught in English language at university level.

A major proportion i.e. 47.3 percent of the respondents were strongly agreed and 42.7 percent of them were agreed with the statement "I feel that English language decreased the superiority of my national language", while only 5.3 percent of them were neutral, 2.7 percent of them were disagreed and only 2.0 percent of the respondents were strongly disagreed with this statement. These finding shows that a huge majority of the youth felt that English language decreased the superiority of their national language.

Most of the respondents i.e. 44.7 percent were strongly agreed and 42.7 percent of them were agreed with the statement "The importance of our national and mother languages decreased by the dominancy of English language", 
while 8.7 percent of them were neutral, 3.3 percent of them were disagreed and only 0.7 percent of the respondent was strongly disagreed with this statement. So a vast majority of the respondents felt that the importance of our national and mother languages decreased by the dominancy of English language.

\subsection{Distribution of the respondents according to their cultural practices (traditional)}

$$
N=150
$$

\begin{tabular}{|c|c|c|c|c|c|c|c|c|c|c|}
\hline \multirow[t]{2}{*}{ Statements } & \multicolumn{2}{|c|}{$\begin{array}{c}\text { Strongly } \\
\text { agree }\end{array}$} & \multicolumn{2}{|c|}{ Agree } & \multicolumn{2}{|c|}{ Neutral } & \multicolumn{2}{|c|}{ Disagree } & \multicolumn{2}{|c|}{$\begin{array}{l}\text { Strongly } \\
\text { disagree }\end{array}$} \\
\hline & F. & $\%$ & F. & $\%$ & F. & $\%$ & F. & $\%$ & F. & $\%$ \\
\hline West diffuse their traditions through cable channels and mass media & 71 & 47.3 & 66 & 44.0 & 6 & 4.0 & 3 & 2.0 & 4 & 2.7 \\
\hline I feel that youth prefer to celebrate international days instead of local days & 51 & 34.0 & 66 & 44.0 & 201 & 13.3 & 12 & 8.0 & 1 & 0.7 \\
\hline I prefer to see films and drama on Eid day & 24 & 16.0 & 523 & 34.7 & 302 & 20.0 & 38 & 25.3 & 6 & 4.0 \\
\hline $\begin{array}{l}\text { I feel that our religious festivals like Eid lost the importance due to cable } \\
\text { channels. }\end{array}$ & 38 & 25.3 & 61 & 40.7 & \begin{tabular}{|l|llllllll}
21 & 1 & & &
\end{tabular} & 14.0 & 21 & 14.0 & 9 & 6.0 \\
\hline I feel that local festivals has lost the importance due to globalization & 49 & 32.7 & 69 & 46.0 & $14[9$ & 9.3 & 15 & 10.0 & 3 & 2.0 \\
\hline $\begin{array}{l}\text { I think that Globalization decreased the value of our ceremonies and } \\
\text { traditions }\end{array}$ & 55 & 36.7 & $67 \mid$ & 44.7 & $14 \mid 9$ & 9.3 & 7 & 4.7 & 7 & 4.7 \\
\hline
\end{tabular}

This Table 5 represents the respondents' opinion about the cultural practices towards traditional. A major proportion i.e. 47.3 percent of the respondents were strongly agreed and 44.0 percent of them were agreed with the statement "West diffuse their traditions through cable channels and mass media", while 4.0 percent of them were neutral, 2.0 percent of them were disagreed and only 2.7 percent of them were strongly disagreed with this opinion. So west diffuse our traditions through cable channels and mass media.

About one-third i.e. 34.0 percent of the respondents were strongly agreed and 44.0 percent of them were agreed with the statement "I feel that youth prefer to celebrate international days instead of local days", while 13.3 percent of them were neutral, 8.0 percent of them were disagreed and only 0.7 percent of them were strongly disagreed with this opinion. So our youth preferred to celebrate international days instead of local days.

Almost 16.0 percent of the respondents were strongly agreed and 34.7 percent of them were agreed with the statement "I prefer to see films and drama on Eid day", while 20.0 percent of them were neutral, 25.3 percent of them were disagreed and 4.0 percent of them were strongly disagreed with this opinion. These findings indicate that about a half of sampled youth preferred to see films and drama on Eid day.

About one-fourth i.e. 25.3 percent of the respondents were strongly agreed and a major proportion i.e. 40.7 percent of them were agreed with the statement "I feel that our religious festivals like Eid lost the importance due to cable channels", while 14.0 percent of them were neutral, another 14.0 percent of them were disagreed and 6.0 percent of them were strongly disagreed with this opinion. These findings clearly show that our youth had opinion that our religious festivals like Eid lost the importance due to cable channels.

More one-third i.e. 36.7 percent of the respondents were strongly agreed and a major proportion i.e. 44.7 percent of them were agreed with the statement "I think that Globalization decreased the value of our ceremonies and traditions", while 9.3 percent of them were neutral, 4.7 percent of them were disagreed and another 4.7 percent of them were strongly disagreed with this opinion. These results reveal that our youth had thinking that Globalization decreased the value of our ceremonies and traditions.

\subsection{Distribution of the respondents according to their appearance and life style}

\begin{tabular}{|c|c|c|c|c|c|c|c|c|c|c|}
\hline \multirow[t]{2}{*}{ Statements } & \multicolumn{2}{|c|}{$\begin{array}{l}\text { Strongly } \\
\text { agree }\end{array}$} & \multicolumn{2}{|c|}{ Agree } & \multicolumn{2}{|c|}{ Neutral } & \multicolumn{2}{|c|}{ Disagree } & \multicolumn{2}{|c|}{$\begin{array}{l}\text { Strongly } \\
\text { disagree }\end{array}$} \\
\hline & $\mathrm{F}$. & $\%$ & $\mathrm{~F}$. & $\%$ & F. & $\%$ & $\mathrm{~F}$. & $\%$ & $\mathrm{~F}$. & $\%$ \\
\hline $\begin{array}{l}\text { I feel that Mass media and TV are promoting new design and } \\
\text { fashion in our society }\end{array}$ & 71 & 47.3 & 67 & 44.7 & 5 & 3.3 & 5 & 3.3 & 2 & 1.3 \\
\hline I impress myself from the TV actors ,s personality & 20 & 13.3 & 54 & 36.0 & 24 & 16.0 & 39 & 26.0 & 13 & 8.7 \\
\hline $\begin{array}{l}\text { In my opinion mass media and cable channels has changed our } \\
\text { life style }\end{array}$ & 52 & 34.7 & 68 & 45.3 & 13 & 8.7 & 12 & 8.0 & 5 & 3.3 \\
\hline I consider television character as my role model & 10 & 6.7 & 35 & 23.3 & 34 & 22.7 & 41 & 27.3 & 30 & 20.0 \\
\hline
\end{tabular}


Table 6 present the respondents' opinion about the appearance and life style. Less than a half i.e. 47.3 percent of the respondents were strongly agreed, 44.7 percent of them were agreed with the statement "I feel that Mass media and TV are promoting new design and fashion in our society", only 3.3 percent of them were neutral, another 3.3 percent of them were disagreed and 1.3 percent of them were strongly disagreed with this statement. So the youth felt that mass media and TV are promoting new design and fashion in their society

Only 13.3 percent of the respondents were strongly agreed, 36.0 percent of them were agreed with the statement "I impress myself from the TV actors' personality", 16.0 percent of them were neutral, 26.0 percent of them were disagreed and 8.7 percent of them were strongly disagreed with this statement.

More than one-third i.e. 34.7 percent of the respondents were strongly agreed and a major proportion i.e. 45.3 percent of them were agreed with the statement "In my opinion mass media and cable channels has changed our life style", 8.7 percent of them were neutral, 8.0 percent of them were disagreed and only 3.3 percent of them were strongly disagreed with this statement. So the youth had opinion that the mass media and cable channels have changed their life style.

Only 6.7 percent of the respondents were strongly agreed, 23.3 percent of them were greed with the statement "I consider television character as my role model", 22.7 percent of them were neutral, 27.3 percent of them were disagreed and 20.0 percent of them were strongly disagreed with this statement. So the youth felt that the television character never their role model.

\subsection{Distribution of the respondents according to their perception towards cultural identity}

$N=150$

\begin{tabular}{|c|c|c|c|c|c|c|c|c|c|c|}
\hline \multirow[t]{2}{*}{ Statements } & \multicolumn{2}{|c|}{$\begin{array}{l}\text { Strongly } \\
\text { agree }\end{array}$} & \multicolumn{2}{|c|}{ Agree } & \multicolumn{2}{|c|}{ Neutral } & \multicolumn{2}{|c|}{ Disagree } & \multicolumn{2}{|c|}{$\begin{array}{l}\text { Strongly } \\
\text { disagree }\end{array}$} \\
\hline & F. & $\%$ & F. & $\%$ & F. & $\%$ & F. & $\%$ & $\mathrm{~F}$. & $\%$ \\
\hline Globalization encourages cultural imperialism in our society & 61 & 40.7 & 66 & 44.0 & 15 & 10.0 & 5 & 3.3 & 3 & 2.0 \\
\hline $\begin{array}{l}\text { I feel westernization diffuse cultural hegemony through media and cable } \\
\text { channels }\end{array}$ & 49 & 32.7 & 86 & 57.3 & 9 & 6.0 & 6 & 4.0 & 0 & 0.0 \\
\hline I feel that globalization promoted homogeneity among youth & 42 & 28.0 & 68 & 45.3 & 23 & 15.3 & 16 & 10.7 & 1 & 0.7 \\
\hline Youth are becoming much familiar of western cultural values & 49 & 32.7 & 77 & 51.3 & 15 & 10.0 & 8 & 5.3 & 1 & 0.7 \\
\hline I feel that Western imperialism decreased our national state sovereignty & 70 & 46.7 & 55 & 36.7 & 15 & 10.0 & 6 & 4.0 & 4 & 2.7 \\
\hline I agree that globalization has declined our artifact and cultural beauty & 46 & 30.7 & 68 & 45.3 & 18 & 12.0 & 16 & 10.7 & 2 & 1.3 \\
\hline I feel that technological advancement changed our family system & 58 & 38.7 & 61 & 40.7 & 14 & 9.3 & 14 & 9.3 & 3 & 2.0 \\
\hline $\begin{array}{l}\text { I feel that our family system changed from extended to nuclear family } \\
\text { system due to technological change }\end{array}$ & 45 & 30.0 & 76 & 50.7 & 13 & 8.7 & 13 & 8.7 & 3 & 2.0 \\
\hline I think that our cultural events are rare shown by media and TV & 41 & 27.3 & 58 & 38.7 & 26 & 17.3 & 17 & 11.3 & 8 & 5.3 \\
\hline Our cultural festivals has lost the importance due to western hegemony & 49 & 32.7 & 66 & 44.0 & 17 & 11.3 & 14 & 9.3 & 4 & 2.7 \\
\hline $\begin{array}{l}\text { I feel that youth being traditional has become modern that effected the } \\
\text { family native cultural identity }\end{array}$ & 56 & 37.3 & 72 & 48.0 & 8 & 5.3 & 12 & 8.0 & 2 & 1.3 \\
\hline I feel that western channels decreased our cultural and ethical norms & 57 & 38.0 & 72 & 48.0 & 12 & 8.0 & 8 & 5.3 & 1 & 0.7 \\
\hline
\end{tabular}

Table 7 presents the respondents' perception towards cultural identity. About 40.7 percent of the respondents were strongly agreed, while 44.0 percent of them were agreed with the statement "Globalization encourages cultural imperialism in our society", while 10.0 percent of them were neutral, 3.3 percent of them were disagreed and only 2.0 percent of them were strongly disagreed with this statement. These results depicts that our youth had perception that globalization encourages cultural imperialism in their society.

Slightly less than one-third i.e. 32.7 percent of the respondents were strongly agreed and a majority i.e. 57.3 percent of them were agreed with the statement "I feel westernization diffuse cultural hegemony through media and cable channels", while 6.0 percent of them were neutral, 4.0 percent of them were disagreed with this statement. So the youth felt that the westernization diffuse cultural hegemony through media and cable channels.

About 28.0 percent of the respondents were strongly agreed and a major proportion i.e. 45.3 percent of them were agreed with the statement "I feel that globalization promoted homogeneity among youth", while 15.3 percent of them were neutral, 10.7 percent of them were disagreed and only one respondent was strongly disagreed with this statement. These results shows that our youth felt that globalization promoted homogeneity among them.

Little less than one-third i.e. 32.7 percent of the respondents were strongly agreed and more than a half i.e. 51.3 percent of them were agreed with the statement "Youth are becoming much familiar of western cultural values", while 
10.0 percent of them were neutral, 5.3 percent of them were disagreed and only one respondent was strongly disagreed with this statement. These findings shows that our youth are becoming much familiar of western cultural values

A major proportion i.e. 46.7 percent of the respondents were strongly agreed and more than one-third i.e. 36.7 percent of them were agreed with the statement "I feel that Western imperialism decreased our national state sovereignty", while 10.0 percent of them were neutral, 4.0 percent of them were disagreed and only 2.7 percent of them were strongly disagreed with this statement. These findings shows that sampled youth felt that Western imperialism decreased their national state sovereignty.

Almost 31 percent of the respondents were strongly agreed and a major proportion i.e. 45.3 percent of them were agreed with the statement "I agree that globalization has declined our artifact and cultural beauty", while 12.0 percent of them were neutral, 10.7 percent of them were disagreed and only 1.3 percent of them were strongly disagreed with this statement. So globalization has declined our artifact and cultural beauty.

About 38.7 percent of the respondents were strongly agreed and a major proportion i.e. 40.7 percent of them were agreed with the statement "I feel that technological advancement changed our family system", while 9.3 percent of them were neutral, another 9.3 percent of them were disagreed and only 2.0 percent of them were strongly disagreed with this statement.

About 30.0 percent of the respondents were strongly agreed and about a half i.e. 50.7 percent of them were agreed with the statement "I feel that our family system changed from extended to nuclear family system due to technological change", while 8.7 percent of them were neutral, another 8.7 percent of them were disagreed and only 2.0 percent of them were strongly disagreed with this statement. So a huge majority of the respondents perceived that our family system changed from extended to nuclear family system due to technological change.

More than one-fourth i.e. 27.3 percent of the respondents were strongly agreed and 38.7 percent of them were agreed with the statement "I think that our cultural events are rare shown by media and TV", while 17.3 percent of them were neutral, 11.3 percent of them were disagreed and 5.3 percent of them were strongly disagreed with this statement. So majority of the respondents had thinking that our cultural events are rare shown by media and TV. About one-third i.e. 32.7 percent of the respondents were strongly agreed and 44.0 percent of them were agreed with the statement "Our cultural festivals has lost the importance due to western hegemony", while 11.3 percent of them were neutral, 9.3 percent of them were disagreed and 2.7 percent of them were strongly disagreed with this statement. So majority of the respondents had thinking that our cultural festivals have lost the importance due to western hegemony.

More than one-third i.e. 37.3 percent of the respondents were strongly agreed and 48.0 percent of them were agreed with the statement "I feel that youth being traditional has become modern that effected the family native cultural identity", while 5.3 percent of them were neutral, 8.0 percent of them were disagreed and 1.3 percent of them were strongly disagreed with this statement. So majority of the respondents had feeling that youth being traditional has become modern that affected the family native cultural identity.

More than one-third i.e. 38.0 percent of the respondents were strongly agreed and 48.0 percent of them were agreed with the statement "I feel that western channels decreased our cultural and ethical norms", while 8.0 percent of them were neutral, 5.3 percent of them were disagreed and 0.7 percent of them were strongly disagreed with this statement. So majority of the respondents felt that western channels decreased our cultural and ethical norms.

\subsection{Indexation}

\begin{tabular}{|l|c|c|c|c|c|c|c|}
\hline Variable & $\begin{array}{c}\text { No. of items in Matrix } \\
\text { Question }\end{array}$ & $\begin{array}{c}\text { No. of categories in Index } \\
\text { variable }\end{array}$ & $\begin{array}{c}\text { Min. } \\
\text { Score }\end{array}$ & $\begin{array}{c}\text { Max. } \\
\text { Score }\end{array}$ & $\begin{array}{c}\text { Mean } \\
\text { Score }\end{array}$ & $\begin{array}{c}\text { Alpha } \\
\text { value }\end{array}$ \\
\hline Technical changes & 23 & 5 & 29 & 71 & 48.49 & 8.89 & .6856 \\
\hline Globalization & 10 & 5 & 10 & 35 & 20.34 & 4.61 & .6993 \\
\hline Westernization & 9 & 5 & 7 & 25 & 15.65 & 3.66 & .9813 \\
\hline
\end{tabular}

\section{Part-B}

\section{Bi-Variate Analysis}

Testing of Hypotheses

Hypothesis 1: Gender is associated with the difference in perception about impact of globalization 
Table 8: Association between sex of the respondents and their perception about the impact of globalization

\begin{tabular}{|c|c|c|c|c|}
\hline \multirow{2}{*}{ Gender } & \multicolumn{2}{|c|}{ Respondents' perception about the impact of globalization } & \multirow{2}{*}{ Total } \\
\cline { 2 - 5 } & Low & Medium & 4 & 75 \\
\hline \multirow{2}{*}{ Male } & 25 & 46 & $5.3 \%$ & $100.0 \%$ \\
\cline { 2 - 5 } & $33.3 \%$ & $61.3 \%$ & 15 & 75 \\
\hline \multirow{2}{*}{ Female } & 18 & 42 & $20.0 \%$ & $100.0 \%$ \\
\cline { 2 - 5 } & $24.0 \%$ & $56.0 \%$ & 19 & 150 \\
\hline \multirow{2}{*}{ Total } & 43 & 88 & $12.7 \%$ & $100.0 \%$ \\
\cline { 2 - 5 } & $28.7 \%$ & $58.7 \%$ & & \\
\hline
\end{tabular}

Chi-square $=7.69$, d.f. $=2$, Significance $=.021^{*}$, Gamma $=-.329,{ }^{*}=$ Significant

Table 9 presents the association between gender and their perception about the impact of globalization. Chi-square value shows a significant association between gender and their perception about the impact of globalization. Gamma value shows a negative relationship between the variables. Its means female respondents had more perception about the impact of globalization as compared to male respondents. So the hypothesis "Gender is associated with the difference in perception about impact of globalization" is accepted.

Hypothesis 2: Higher the adoption of technical changes, the positive will be perception about impact of globalization

Table 9: Association between respondents' adoption of technical changes and their perception about the impact of globalization

\begin{tabular}{|c|c|c|c|c|}
\hline \multirow{2}{*}{ Technical changes } & \multicolumn{2}{|c|}{ Respondents' perception about the impact of globalization } & \multirow{2}{*}{ Total } \\
\cline { 2 - 5 } & Low & Medium & 1 & 49 \\
\hline \multirow{2}{*}{ Low } & 24 & 24 & $2.0 \%$ & $100.0 \%$ \\
\cline { 2 - 5 } & $49.0 \%$ & $49.0 \%$ & 11 & 69 \\
\hline \multirow{2}{*}{ Medium } & 19 & 39 & $15.9 \%$ & $100.0 \%$ \\
\cline { 2 - 5 } & $27.5 \%$ & $56.5 \%$ & 7 & 32 \\
\cline { 2 - 5 } High & - & 25 & $21.9 \%$ & $100.0 \%$ \\
\hline \multirow{2}{*}{ Total } & 43 & $88.1 \%$ & 19 & 150 \\
\cline { 2 - 5 } & $28.7 \%$ & $58.7 \%$ & $12.7 \%$ & $100.0 \%$ \\
\hline
\end{tabular}

Chi-square $=26.25$, d.f. $=4$, Significance $=.000^{\star \star}$, Gamma $=.602,{ }^{* *}=$ Highly-Significant

Table 14 presents the association between respondents' perception about the technical changes and their perception about the impact of globalization. Chi-square value shows a highly-significant association between respondents' perception about the technical changes and their perception about the impact of globalization. Gamma value shows a strong positive relationship between the variables. It means if the respondents had more observation about technical changes, then they had also high perception about the impact of globalization. So the hypothesis "Higher the adoption of the technical changes, the positive will be perception about impact of globalization" is accepted.

Hypothesis 3:Higher the adoption of western patterns, more will be the impact of globalization

Table 10: Association between respondents' adoption of westernization and the impact of globalization

\begin{tabular}{|c|c|c|c|c|}
\hline \multirow{2}{*}{ Westernization } & \multicolumn{2}{|c|}{ Respondents' perception about the impact of globalization } & \multirow{2}{*}{ Total } \\
\cline { 2 - 5 } & Low & Medium & 2 & 61 \\
\hline \multirow{2}{*}{ Low } & 23 & 36 & $3.3 \%$ & $100.0 \%$ \\
\cline { 2 - 5 } & $37.7 \%$ & $59.0 \%$ & 12 & 66 \\
\hline \multirow{2}{*}{ Medium } & 14 & 40 & 5 & $100.0 \%$ \\
\cline { 2 - 5 } & $21.2 \%$ & $60.6 \%$ & $21.7 \%$ & 23 \\
\cline { 2 - 5 } High & 6 & 12 & 19 & $100.0 \%$ \\
\hline \multirow{2}{*}{ Total } & $26.1 \%$ & $52.2 \%$ & $12.7 \%$ & 150 \\
\cline { 2 - 5 } & 43 & 88 & $58.0 \%$ \\
\hline
\end{tabular}

Chi-square $=10.60$, d.f. $=4$, Significance $=.031^{*}$, Gamma $=.333,{ }^{*}=$ Significant 
Table 10 presents the association between respondents' perception about westernization and their perception about the impact of globalization. Chi-square value shows a significant association between respondents' perception about the westernization and their perception about the impact of globalization. Gamma value shows a strong positive relationship between the variables. It means if the respondents had more perception about the westernization, then they had also high perception about the impact of globalization. So the hypothesis "Higher the adoption of western patterns, more will be the impact of globalization" is accepted.

\section{Conclusion}

In this research it is investigated that whether globalization influence on the socio-cultural identity among youth. Globalization has enormous effect on the cultural identity among youth through technological changes and western imperialism. The statistical analysis of this research activity concludes that globalization has great impact on the interaction pattern, cultural practices, and life style. The domination of universally approved perception and prevalence of globalization has its in-depth and evident impacts over youth c local culture because it has caused decline of traditional cultural norms and values which has been replaced by the western values. The influence of globalization is decreased the importance of local cultural practices. The Chi-square value was highly significant, which enumerates that was used to identify the relationship between globalization and socio-cultural identity. The hypothesis "Higher the observation about the technical changes, more will be the perception about impact of globalization was accepted". So the results of the study show that West diffuses their culture through cable channels and dominant western culture has decreased the youth local cultural identity.

\section{References}

Appadurai, A. (1996). Modernity at large. Cultural dimensions of globalization. Minneapolis: University of Minnesota Press.

Beck, U. (2000) WHAT IS Globalization? Cornwall: MPG Books, Bodmin Ltd.

Castells, M. (1996). The rise of network the society. Oxford: Blackwell Publishing.

Castells, M. (1997) The Power of Identity, vol. II of The Information Age: Economy, Society and Culture. Oxford: Blackwell.

Deng, N. (2005). On the national literature's tactics in the globalization's language environment. Journal of Human Institute of Humanities, Science and Technology, 1, 39- 41.

Furlong, A \& Cartmel, F. (2007). Young People and Social Change, second edition, Open UniversityPress/ McGrawHill, Buckingham. http://www.developmenteducationreview.com

Giddens, A. (1991).Modernity and Self-Identity: Self and Society in the Late Modern Polity Press, Cambridge.

Harvey, D. (2003). Young People in a Globalizing World, World Youth Report, New York.

John T. (1999). Globalization and Culture, Chicago: University of Chicago Press, p22

Livesey, C. (2004). Culture and identity, Sociological Pathways. http://www. sociology.org.uk/pathway2.htm.

Parks, Malcolm R. and Kory Floyd. (1996). "Making Friends in Cyberspace." Journal of Communication 46(1).

Ray, L. (2007).Globalization and Everyday Life, Routledge, Abingdon.

http:// www.developmenteducationreview.com

Robertson, R. (1992). Globalization: Social Theory and Global Culture, Sage, London.

Santos-Paulino, (2005). Trade Liberalization and Economic Performance: Theory and Evidence for Developing Countries. The World Economy. 28 (6): 783-821.

Sekeran, R.B. (2010). Research Methods for Bussiness.

Tajfel, Henry. (1984). "Social Categories of Human Groups.", Editorial Herder, Barcelona.

Tomlinson, J. (1991). Cultural Imperialism: A Critical Introduction. London: Pinter.

Tomlinson, J. (1999) Globalization and Culture. Cambridge: Polity Press.

Tuo,C. (1998). "Globalization and Contemporary International Relation", Marxism and Reality, (3), p20.

Urry, J. (2003). Global Complexity, Polity Press, Cambridge

Walsham, G. (2001). Making a world of difference -IT in a Global context. UK: Jon Wiley \& Sons.

Waters, M. (1995). Globalization. London: Routledge.

Wimmer, R. D., \& Dominick, J. R. (1993). Qualitative Research Methods. Mass Media Research. (pp. 63-64, 139-161, 342, 512). California: Wadsworth Publishing Company. 